\title{
Aza-Reversine Promotes Reprogramming of Lung (MRC-5) and Differentiation of Mesenchymal Cells into Osteoblasts
}

\author{
Fani Tsitouroudi ${ }^{1}$, Vasiliki Sarli ${ }^{1, *} \mathbb{*}$, Dimitrios Poulcharidis ${ }^{1}\left(\mathbb{D}\right.$, Maria Pitou ${ }^{1} \oplus$, Alexandros Katranidis ${ }^{2} \mathbb{D}$ \\ and Theodora Choli-Papadopoulou ${ }^{1, *}$ \\ 1 Department of Chemistry, Aristotle University of Thessaloniki, University Campus, 54124 Thessaloniki, \\ Greece; fanioli@gmail.com (F.T.); dimitris.poulcharidis@hotmail.com (D.P.); margeopit@chem.auth.gr (M.P.) \\ 2 Institute of Biological Information Processing IBI-6, Forschungszentrum Jülich (FZJ), 52425 Jülich, Germany; \\ a.katranidis@fz-juelich.de \\ * Correspondence: sarli@chem.auth.gr (V.S.); tcholi@chem.auth.gr (T.C.-P.)
}

\section{check for}

updates

Citation: Tsitouroudi, F.; Sarli, V.; Poulcharidis, D.; Pitou, M.;

Katranidis, A.; Choli-Papadopoulou,

T. Aza-Reversine Promotes

Reprogramming of Lung (MRC-5)

and Differentiation of Mesenchymal Cells into Osteoblasts. Materials 2021, 14, 5385. https://doi.org/10.3390/ ma14185385

Academic Editor:

Shin-ichi Kawaguchi

Received: 28 July 2021

Accepted: 14 September 2021

Published: 17 September 2021

Publisher's Note: MDPI stays neutral with regard to jurisdictional claims in published maps and institutional affiliations.

Copyright: (c) 2021 by the authors. Licensee MDPI, Basel, Switzerland. This article is an open access article distributed under the terms and conditions of the Creative Commons Attribution (CC BY) license (https:/ / creativecommons.org/licenses/by/ $4.0 /)$.
Abstract: Reversine or 2-(4-morpholinoanilino)-N6-cyclohexyladenine was originally identified as a small organic molecule that induces dedifferentiation of lineage-committed mouse myoblasts, $\mathrm{C} 2 \mathrm{C} 12$, and redirects them into lipocytes or osteoblasts under lineage-specific conditions (LISCs). Further, it was proven that this small molecule can induce cell cycle arrest and apoptosis and thus selectively lead cancer cells to cell death. Further studies demonstrated that reversine, and more specifically the $\mathrm{C} 2$ position of the purine ring, can tolerate a wide range of substitutions without activity loss. In this study, a piperazine analog of reversine, also known as aza-reversine, and a biotinylated derivative of aza-reversine were synthesized, and their potential medical applications were investigated by transforming the endoderm originates fetal lung cells (MRC-5) into the mesoderm originated osteoblasts and by differentiating mesenchymal cells into osteoblasts. Moreover, the reprogramming capacity of aza-reversine and biotinylated aza-reversine was investigated against MRC- 5 cells and mesenchymal cells after the immobilization on PMMA/HEMA polymeric surfaces. The results showed that both aza-reversine and the biofunctionalized, biotinylated analog induced the reprogramming of MRC-5 cells to a more primitive, pluripotent state and can further transform them into osteoblasts under osteogenic culture conditions. These molecules also induced the differentiation of dental and adipose mesenchymal cells to osteoblasts. Thus, the possibility to load a small molecule with useful "information" for delivering that into specific cell targets opens new therapeutic personalized applications.

Keywords: aza-reversine; cell reprogramming; MRC-5 cells; mesenchymal cells; immobilization of aza-reversine; PMMA-HEMA surfaces

\section{Introduction}

Stem cells are unique cells that are able to self-renew and differentiate into specific cell types under proper conditions. Their key role in cellular processes during embryonic development and tissue homeostasis stem cells offer great potential in the treatment of various diseases, including type I diabetes [1,2], muscular dystrophies, bone diseases, cancer, neurodegenerative and cardiovascular [3] disorders [4]. Major drawbacks in their applications arise from their scarce availability and difficulty in controlling cell fate. However, recent achievements have allowed the reprogramming of somatic cells to induced pluripotent stem cells by defined genetic factors or by small molecules [5]. In this context, reversine was identified as a novel dedifferentiation factor of lineage-committed mouse myoblasts $\mathrm{C} 2 \mathrm{C} 12$, which were redirected into lipocytes or osteoblasts, under lineage-specific conditions (LISCs) [6]. Since then, reversine has become a particularly useful tool for the study of the control of cell fate. According to Anastasia and coworkers, reversine was able to transform primary murine and human dermal fibroblasts into myogenic-competent cells in vitro and in vivo [7]. It also induced adipocyte differentiation in 3T3-L1 cells [8] and 
increased the plasticity of $\mathrm{C} 2 \mathrm{C} 12$ myoblasts towards the neuroectodermal line [9]. Lineagecommitted annulus fibrosus cells dedifferentiated into progenitor-like cells after treatment with reversine [10] and porcine muscle-derived stem cells (PMDSCs) were transformed into female germ-like cells based on the reports of Saraiya and Lv, respectively [11]. All the aforementioned studies focused on the effect of reversine on mesoderm-derived cells, which were transformed into cells of the mesodermal, endodermal or germ line. Further studies revealed that reversine can be employed not only as a dedifferentiation factor but also for the enhancement of the differentiation ability of mesenchymal stem cells [12].

Considering the molecular targets of reversine, it was previously demonstrated that it is a moderately potent antagonist for the human $\mathrm{A} 3$ adenosine receptor with a Ki value of $0.66 \mu \mathrm{M}$ [13] and a dual inhibitor of MEK1 (IC50 > 1.5 $\mu \mathrm{M}$ ) and nonmuscle myosin II heavy chain (IC50 $>0.35 \mu \mathrm{M}$ ) [14]. Moreover, it inhibits multiple mitotic kinases, such as Aurora kinase A $($ IC50 $=0.15 \mu \mathrm{M}), \mathrm{B}(\mathrm{IC} 50=0.5 \mu \mathrm{M}), \mathrm{C}(\mathrm{IC} 50=0.4 \mu \mathrm{M})$ and human MPS1 with an IC50 value of $2.8 \mathrm{nM}$ [15-17]. Further preliminary studies on reversines' analogs that exhibit the same or greater effects have been conducted. A structure-activity relationship (SAR) analysis gave light to reversine's substitution sites and concluded that its activity is determined by both the $\mathrm{N} 9$ hydrogen and the $\mathrm{NH}$ substitution at the $\mathrm{C} 2$ position of the purine ring. On the contrary, dedifferentiating effects are retained after substitution of primary amines at the $\mathrm{C} 6$ position of the purine ring [18].

In this context, and along with the fact that there are no published data for reversine immobilization, a reversine analog that can be tagged with biotin was synthesized. The biotin-streptavidin bond compromises the strongest non-covalent bond occurring naturally and is used widely for the immobilization of molecules on materials or nanotubes in applications of nanotechnology. Thus, the biotinylation of reversine allows its immobilization on nanomaterials for manufacturing transplants or on nanocarriers for selective cancer treatment. This study was orientated towards the synthesis of a reversine analog, aza-reversine, that can be biotinylated via a peptide bond formation, the effect of this analog and its biotinylated counterpart on MRC-5 cell reprogramming to osteoblasts under osteogenic-inducing conditions. Further, their differentiation capacity on mesenchymal stem cells was also evaluated and discussed in this paper.

\section{Methods}

\subsection{General Experimental Details}

All reactions were carried out under an atmosphere of Ar unless otherwise specified. All commercial reagents were used without further purification. Reactions were monitored by TLC with visualization by UV light and visualizing agent aqueous ceric sulfate/phosphomolybdic acid or ethanolic p-anisaldehyde solution. ${ }^{1} \mathrm{H}$ and ${ }^{13} \mathrm{C}$ NMR spectra were acquired on NMR instruments (Bruker Avance III 300, Madison, WI, USA; Agilent $500 \mathrm{MHz}$, Palo Alto, CA, USA) at 300, 500 and 75, $125 \mathrm{MHz}$, respectively. Mass spectra data were acquired on a mass spectrometer (Hybrid Ion Trap-Orbitrap Mass Spectrometer, Thermo Fisher Scientific, Waltham, MA, USA) equipped with an electrospray ion source in positive mode (source voltage $3.5 \mathrm{kV}$, sheath gas flow 10, capillary temperature $275^{\circ} \mathrm{C}$ ) with resolution $\mathrm{R}=60.000$ at $\mathrm{m} / z=400$ (mass range $=150-2000$ ) and dioctylphtalate $(m / z=391.28428)$ as the "lock mass". The surface of the samples was analyzed by infrared spectroscopy using an FTIR spectrometer Spectrum One (Perkin Elmer, Wellesley, Boston, MA, USA) and was analyzed in triplicates. A horizontal attenuated total reflection (HATR) accessory was used with a Zinc Selenide (ZnSe) plate, and each spectrum was obtained between 4000 and $600 \mathrm{~cm}^{-1}$ with a resolution of $4 \mathrm{~cm}^{-1}$. Data processing and calculation were conducted with the commercial software Spectrum v5.0.1 (Perkin Elmer LLC 1500F2429, Waltham, MA, USA).

\subsection{Tert-Butyl 4-(4-Aminophenyl)piperazine-1-carboxylate, $S 1$}

To a solution of 1-(4-aminophenyl)piperazine $(350 \mathrm{mg}, 1.97 \mathrm{mmol})$ in anhydrous $\mathrm{CH}_{2} \mathrm{Cl}_{2}(11 \mathrm{~mL})$ at $0{ }^{\circ} \mathrm{C}$, di-tert-butyl di-carbonate $(406 \mathrm{mg}, 1.86 \mathrm{mmol})$ was added. The 
resulting mixture was stirred at $0{ }^{\circ} \mathrm{C}$ for $2 \mathrm{~h}$, poured into brine $(10 \mathrm{~mL})$, alkanilized with $1 \mathrm{~N}$ $\mathrm{NaOH}$ and extracted with $\mathrm{CH}_{2} \mathrm{Cl}_{2}(3 \times 15 \mathrm{~mL})$. The combined organic layers were washed with $\mathrm{H}_{2} \mathrm{O}$, dried $\left(\mathrm{Na}_{2} \mathrm{SO}_{4}\right)$ and the solvent was evaporated under vacuum. Purification by flash chromatography (eluent; hexane/ethyl acetate $=1 / 1$ ) afforded S1 $(413 \mathrm{mg})$ in 80\% yield as a brown solid. ${ }^{1} \mathrm{H}$ NMR data is in accordance with the literature [19]. S1: ${ }^{1} \mathrm{H}$ NMR $\left(500 \mathrm{MHz}, \mathrm{CDCl}_{3}\right) \delta 6.80(\mathrm{~d}, J=8.5 \mathrm{~Hz}, 2 \mathrm{H}), 6.65(\mathrm{~d}, J=8.5 \mathrm{~Hz}, 2 \mathrm{H}), 3.56(\mathrm{~s}, 4 \mathrm{H}), 2.96(\mathrm{~s}$, $4 \mathrm{H}), 1.47$ (s, 9H); ${ }^{13} \mathrm{C}$ NMR (125 MHz, $\left.\mathrm{CDCl}_{3}\right)$ 154.7, 144.4, 140.6, 119.2, 116.1, 79.7, 51.2, 28.4; HRMS $m / z$ for $\mathrm{C}_{15} \mathrm{H}_{24} \mathrm{~N}_{3} \mathrm{O}_{2}[\mathrm{M}+\mathrm{H}]^{+}$calculated 278.1869, found 278.1860 (Figure S1).

\subsection{N-Cyclohexyl-2-fluoro-9H-purin-6-amine, S2}

Cyclohexylamine $(90 \mu \mathrm{L}, 0.782 \mathrm{mmol})$ and DIPEA $(181 \mu \mathrm{L}, 1.04 \mathrm{mmol})$ were added successively to a solution of compound $3(150 \mathrm{mg}, 0.869 \mathrm{mmol})$ in $n$-butanol $(3 \mathrm{~mL})$. Subsequently, the reaction mixture was heated to $80^{\circ} \mathrm{C}$ with vigorous stirring for $24 \mathrm{~h}$. The solvent was evaporated, and the crude material was used for the next step without further purification. HRMS $m / z$ for $\mathrm{C}_{11} \mathrm{H}_{15} \mathrm{FN}_{5}[\mathrm{M}+\mathrm{H}]^{+}$calcd 236.1311, found 236.1306 [13].

\subsection{Tert-Butyl 4-(4-(6-(Cyclohexylamino)-9H-purin-2-ylamino) phenyl) piperazine-1-carboxylate, 4}

A mixture of 2-fluoro-6-cyclohexylamino-purine $(0.869 \mathrm{mmol})$ in ethanol $(1.7 \mathrm{~mL})$ and S1 $(482 \mathrm{mg}, 1.738 \mathrm{mmol})$ was stirred at $110^{\circ} \mathrm{C}$ for $48 \mathrm{~h}$. The mixture was evaporated in vacuum and the crude material was purified by flash chromatography (eluent; ethyl acetate $/ \mathrm{methanol} /$ triethylamine $=10 / 0.5 / 0.02)$ to afford $346 \mathrm{mg}$ of 4 as a yellow solid $(81 \%$ yield over two steps). 4: m.p. $=96-98{ }^{\circ} \mathrm{C} ;{ }^{1} \mathrm{H}$ NMR $\left(500 \mathrm{MHz}, \mathrm{CDCl}_{3}\right) \delta 12.78(\mathrm{~s}, 1 \mathrm{H}), 7.43$ $(\mathrm{d}, J=8.3 \mathrm{~Hz}, 2 \mathrm{H}), 6.91(\mathrm{~d}, J=8.3 \mathrm{~Hz}, 2 \mathrm{H}), 6.73(\mathrm{~s}, 1 \mathrm{H}), 5.57(\mathrm{~s}, 1 \mathrm{H}), 4.08(\mathrm{~s}, 1 \mathrm{H}), 3.58(\mathrm{~s}, 4 \mathrm{H})$, $3.07(\mathrm{~s}, 4 \mathrm{H}), 2.09(\mathrm{~d}, J=12.4 \mathrm{~Hz}, 2 \mathrm{H}), 1.78(\mathrm{~d}, J=12.7 \mathrm{~Hz}, 2 \mathrm{H}), 1.66(\mathrm{~d}, J=12.4 \mathrm{~Hz}, 1 \mathrm{H}), 1.49$ $(\mathrm{s}, 9 \mathrm{H}), 1.42(\mathrm{dd}, J=24.7,12.6 \mathrm{~Hz}, 1 \mathrm{H}), 1.35-1.15(\mathrm{~m}, 4 \mathrm{H}) ;{ }^{13} \mathrm{C}$ NMR $\left(126 \mathrm{MHz}, \mathrm{CDCl}_{3}\right) \delta$ 157.1, 154.7, 154.4, 147.8, 135.6, 132.9, 123.0, 117.8, 117.3, 114.5, 79.8, 50.2, 49.2, 43.5, 33.3, 28.4, 25.6, 24.9; FT-IR: 3472, 2873, 1652, 1558, 1540, 1496, 1457, 1305, 1275, 1195, 1016, 958, 871; HRMS $m / z$ for $\mathrm{C}_{26} \mathrm{H}_{37} \mathrm{~N}_{8} \mathrm{O}_{2}[\mathrm{M}+\mathrm{H}]^{+}$calcd 493.3039, found 493.3016 (Figures $\mathrm{S} 2$ and S3).

\subsection{N6-Cyclohexyl-N2-(4-(piperazin-1-yl) phenyl)-9H-purine-2,6-diamine, 2}

Compound 4 (93 mg, $0.189 \mathrm{mmol}$ ) was dissolved in $1 \mathrm{~mL} 5 \mathrm{~N} \mathrm{HCl}$ in isopropanol and the mixture was stirred at room temperature for $2 \mathrm{~h}$. The solution was then neutralized with $\mathrm{NaHCO}_{3}$ and the aqueous layer was extracted with ethyl acetate $(3 \times 3 \mathrm{~mL})$. The combined extracts were dried $\left(\mathrm{Na}_{2} \mathrm{SO}_{4}\right)$, filtered and concentrated. The crude material was purified by flash chromatography (eluent; ethyl acetate $/$ methanol $/$ ammonium hydroxide $=10 / 1 / 0.01$ ) to afford $72 \mathrm{mg}$ of 2 in a $97 \%$ yield. 2: $1 \mathrm{H}$ NMR $\left(500 \mathrm{MHz}, \mathrm{CD}_{3} \mathrm{OD}\right) \delta 7.73(\mathrm{~s}, 1 \mathrm{H}), 7.58(\mathrm{~d}$, $\mathrm{J}=8.5 \mathrm{~Hz}, 2 \mathrm{H}), 6.93(\mathrm{~d}, \mathrm{~J}=8.7 \mathrm{~Hz}, 2 \mathrm{H}), 4.09(\mathrm{~s}, 1 \mathrm{H}), 3.07(\mathrm{dd}, \mathrm{J}=19.0,5.1 \mathrm{~Hz}, 4 \mathrm{H}), 2.98(\mathrm{~d}$, $\mathrm{J}=3.8 \mathrm{~Hz}, 4 \mathrm{H}), 2.10(\mathrm{~d}, \mathrm{~J}=12.2 \mathrm{~Hz}, 2 \mathrm{H}), 1.83(\mathrm{~d}, \mathrm{~J}=13.3 \mathrm{~Hz}, 2 \mathrm{H}), 1.69(\mathrm{~d}, \mathrm{~J}=12.6 \mathrm{~Hz}, 1 \mathrm{H})$, 1.59-1.13 (m, 5H); ${ }^{13} \mathrm{C}$ NMR (126 MHz, CD $\left.\mathrm{OD}\right) \delta 158.9,155.1,152.8,148.1,137.6,136.3$, 121.8, 118.7, 114.1, 52.7, 50.6, 46.7, 34.2, 27.0, 26.3; FT-IR: 3413, 2927, 2851, 1617, 1512, 1478, $1414,1240,1151,1043,925,821$; HRMS $m / z$ for $\mathrm{C}_{21} \mathrm{H}_{29} \mathrm{~N}_{8}[\mathrm{M}+\mathrm{H}]^{+}$calcd 393.2515, found 393.2508 (Figure S4).

2.6. (3. aS,4S,6aR)-4-(5-(4-(4-((6-(Cyclohexylamino)-9H-purin-2-yl)amino)phenyl)piperazin-1yl)-5-oxopentyl) Tetrahydro-1H-thieno[3,4-d] imidazol-2(3H)-one, 5

To a solution of compound $2(25 \mathrm{mg}, 0.064 \mathrm{mmol})$ in $0.6 \mathrm{~mL}$ dry DMF 1-ethyl-3-(3dimethylaminopropyl)carbodiimide (13 $\mathrm{mg}, 0.067 \mathrm{mmol}), \mathrm{N}, \mathrm{N}$-dimethylaminopyridine $(10 \mathrm{mg}, 0.081 \mathrm{mmol})$ and $15 \mathrm{mg}(0.063 \mathrm{mmol})$ of biotin at $0{ }^{\circ} \mathrm{C}$ were added. Next, the reaction mixture was stirred overnight at the ambient temperature. The solution was then concentrated under vacuum and the residue was purified by flash chromatography (eluent; dichloromethane/methanol $\left./ \mathrm{NH}_{4} \mathrm{OH}=7 / 1 / 0.01\right)$ to afford $30 \mathrm{mg}$ of 5 as a white solid $(75 \%$ yield). 5: m.p. $=223-225^{\circ} \mathrm{C} ;{ }^{1} \mathrm{H}$ NMR $\left(500 \mathrm{MHz}, \mathrm{CDCl}_{3}-\mathrm{CD}_{3} \mathrm{OD}\right) \delta 7.57-7.50(\mathrm{~m}, 3 \mathrm{H}), 6.92$ $(\mathrm{d}, \mathrm{J}=8.6 \mathrm{~Hz}, 2 \mathrm{H}), 4.60-4.42(\mathrm{~m}, 1 \mathrm{H}), 4.41-4.27(\mathrm{~m}, 1 \mathrm{H}), 4.06(\mathrm{~s}, 1 \mathrm{H}), 3.78$ (brs, $4 \mathrm{H}), 3.65(\mathrm{~s}$, $4 \mathrm{H}), 3.39(\mathrm{~s}, 1 \mathrm{H}), 3.12(\mathrm{~m}, 4 \mathrm{H}), 2.83(1 \mathrm{H}$ missing due to overlapping), $2.72(\mathrm{~d}, \mathrm{~J}=12.9 \mathrm{~Hz}$, 
$1 \mathrm{H}), 2.41(\mathrm{t}, \mathrm{J}=7.2 \mathrm{~Hz}, 2 \mathrm{H}), 2.11(\mathrm{~d}, \mathrm{~J}=10.9 \mathrm{~Hz}, 2 \mathrm{H}), 1.83-1.67(\mathrm{~m}, 7 \mathrm{H}), 1.58-1.20(\mathrm{~m}, 7 \mathrm{H})$; ${ }^{13} \mathrm{C}$ NMR $\left(126 \mathrm{MHz}, \mathrm{CDCl}_{3}-\mathrm{CD}_{3} \mathrm{OD}\right) \delta 171.6,163.7,156.8,153.9,146.1,135.1,134.1,120.9$, $120.8,117.7,113.6,61.7,59.9,55.3,50.4,45.6,41.6,40.3,32.8,32.5,29.5,28.4,28.1,25.5,24.8$; FT-IR: $3276,2924,2853,1685,1624,1560,1508,1425,1327,1226,1150,1117,1031,979,945$, 823, 767; HRMS $m / z$ for $\mathrm{C}_{31} \mathrm{H}_{43} \mathrm{~N}_{10} \mathrm{O}_{2} \mathrm{~S}[\mathrm{M}+\mathrm{H}]^{+}$calcd 619.3291, found 619.3282 (Figure S5).

\subsection{Chemical Modification of Polymeric PMMA/HEMA Surfaces}

According to previous studies, PMMA/HEMA surfaces can be further modified to biofunctionalize a great variety of molecules. Compound 5 was immobilized on PMMA/HEMA surfaces through the non-covalent bond of streptavidin-biotin, as previously described [20]. It is known that streptavidin can simultaneously bind four biotin molecules. Thus, PMMA/HEMA surfaces were modified with biotin groups in order to non-covalently bind streptavidin and laterally bind the biotinylated molecule.

\subsection{Cell Culture}

Dental pulp mesenchymal stem cells were kindly provided by Assistant Professor A. Bakopoulou from the School of Dentistry, Aristotle University of Thessaloniki, and were collected by the enzymatic dissociation method described in Bakopoulou et al. (2016) [21]. The samples had been collected in accordance with all the relevant guidelines and regulations and had been approved by the Institutional Review Board of the Aristotle University of Thessaloniki (Nr. 66/18 June 2018). Adipose mesenchymal cells were kindly provided by Professor G. Koliakos from Biohellenika A.E. Lung cells (MRC-5) were supplied by ATCC (CCL-171). Mesenchymal cells and MRC-5 cells were cultured in Dulbecco's modified eagle medium (Gibco) supplemented with 10\% fetal bovine serum (Gibco) and 1\% penicillin/streptomycin mixture (Gibco) at $37^{\circ} \mathrm{C}$ in a humidified atmosphere containing $5 \% \mathrm{CO}_{2}$. After reaching $80 \%$ of confluency, cells were collected with PBS 1 Xusing a spatula and were centrifuged at $1100 \mathrm{rpm}$ for $3 \mathrm{~min}$. The cell pellet was resuspended in a complete medium (DMEM supplemented with $10 \% \mathrm{FBS}$ and $1 \%$ penicillin/streptomycin). MRC-5 cells and mesenchymal stem cells within the early passage (passage 2) were placed in 12well plates in 5000 cells/well and 20,000/well, respectively. After $24 \mathrm{~h}$, attached cells were treated with aza-reversine or its biotinylated form $(100 \mathrm{nM} /$ well $)$ for $24 \mathrm{~h}$ for mesenchymal cells or $96 \mathrm{~h}$ for MRC-5 cells. After the elapsed time, the medium of mesenchymal or MRC- 5 cells was replaced with osteogenic medium (StemPro ${ }^{\circledR}$ Osteogenesis Differentiation Kit, Invitrogen, Waltham, MA, USA), respectively. Every 2-3, days the osteogenic medium was renewed.

Regarding cell cultures on modified surfaces with aza-reversine 5 , they were placed in 12-well plates and cells were added to them in an appropriate number (5000 MRC-5 cells/well, 20,000 mesenchymal stem cells/well). The cells were cultured with osteogenic medium surfaces, which were changed every $2-3$ days.

\subsection{Alkaline Phosphatase Assay}

Alkaline phosphatase consists of a remarkable biomarker used during in vitro bone formation and osteogenic differentiation, and its activity is enhanced during these processes. It can be detected in proliferating osteoblasts during the 7th and 14th day of osteogenesis, which are stained blue-purple, while control cells are not painted (control mesenchymal cells may differentiate spontaneously in a small percentage). After 14 days of differentiation, the osteogenic medium was removed from the wells, and the cells were washed with PBS 1X. Cells were treated with neutral buffered formalin $(10 \% v / v)$ for $60 \mathrm{~s}$, and after the elapsed time, the neutral buffered formalin was removed. The cells were washed with washing buffer $(0.05 \% v / v$ Tween-20 to Dulbecco's PBS), and the substrate solution BCIP/NBT was added to the cultures. After incubation for 5-10 min at RT in the dark, the substrate solution was removed, cells were washed with washing buffer, and PBS $1 \mathrm{X}$ was added in the end. Images were taken with a Nikon Microscope at $40 \times$ magnification. 


\subsection{Alizarin Red Staining}

Alizarin red staining can detect extracellular calcium deposits formed during in vitro osteogenesis. By using this assay, differentiated cells appear bright orange-red while undifferentiated cells are slightly reddish-pink or colorless. After 21 days of differentiation, the osteogenic medium was removed, cells were washed with Dulbecco's PBS (Gibco) and treated with neutral buffered formalin $(10 \% v / v)$ for $30 \mathrm{~min}$. Afterward, neutral buffered formalin was removed, cells were washed with distilled water and treated with alizarin red staining solution ( $2 \% w / v$ in distilled water, $\mathrm{pH} 4.1-4.3)$ for 20 min at $\mathrm{RT}$ in the dark. After the elapsed time, the staining solution was removed, cells were washed four times with $1 \mathrm{~mL}$ distilled water, and PBS was added at the end. Images were taken with a Nikon Microscope at $40 \times$ magnification.

\subsection{Reverse-Transcription Polymerase Chain Reaction (rt-PCR)}

After 12 days of osteogenic differentiation, cells were collected with PBS 1x using a spatula. Total RNA was isolated from cells with a NucleoSpin ${ }^{\circledR}$ RNA/Protein kit (Macherey-Nagel), and rt-PCR was performed for osteocalcin (OC), which is a specific marker of osteoblasts and for b-glucuronidase (GusB), which is a housekeeping gene and was used as control. The primers that were used for osteocalcin were: forward primer $5^{\prime}$ ACACTCCTCGCCCTATTG- $3^{\prime}$ and reverse primer $5^{\prime}$-GATGTGGTCAGCCAACTC- $3^{\prime}$. The primers used for b-glucuronidase were: forward primer $5^{\prime}$-TACGAACGGGAGGTGATCCT$3^{\prime}$ and reverse primer $5^{\prime}$-TGGCGATAGTGATTCGGAGC- $3^{\prime}$. The rt-PCR reaction was conducted with a RobusT ${ }^{\mathrm{TM} I}$ kit (Finnzymes) using the following conditions: RNA denaturation at $68{ }^{\circ} \mathrm{C}$ for $2 \mathrm{~min}, \mathrm{cDNA}$ synthesis at $50{ }^{\circ} \mathrm{C}$ for $10 \mathrm{~min}$ and at $55^{\circ} \mathrm{C}$ for another $10 \mathrm{~min}$, deactivation of AMV-RT and denaturation of mRNA-cDNA hybrid at $94{ }^{\circ} \mathrm{C}$ for 2 min. cDNA was amplified for 30 cycles with the following conditions: denaturation at $94{ }^{\circ} \mathrm{C}$ for $1 \mathrm{~min}$, annealing at $60{ }^{\circ} \mathrm{C}$ for $1 \mathrm{~min}$, extension at $72{ }^{\circ} \mathrm{C}$ for $1 \mathrm{~min}$ followed by $5 \mathrm{~min}$ at $72{ }^{\circ} \mathrm{C}$ at the end of 30 cycles. The samples were electrophoresed on agarose gel at 100 Volt for $25 \mathrm{~min}$.

\section{Results and Discussion}

\subsection{Chemical Synthesis of Aza-Reversine 2 and Biotinylated Aza-Reversine 5}

Previous structure-activity relationship studies by Schultz and coworkers [14] showed that the $\mathrm{C} 2$ position of the purine ring in reversine can tolerate a wide range of substitutions. In consequence, aza-reversine 2 was chosen as a suitable substrate because it can be conjugated with a biotin tag via a peptide bond formation with the free amino group in the piperazine ring (Scheme 1). Substitution of the commercially available 6-chloro-2fluoropurine (3) first with cyclohexylamine following the protocols reported by Ding [6] and Perreira [13] and then with tert-butyl 4-(4-aminophenyl)piperazine-1-carboxylate afforded the key intermediate 4 at an $81 \%$ yield (over the two steps) [19]. After removal of the $\mathrm{N}$-Boc group in 4 using $4 \mathrm{~N} \mathrm{HCl}$ in isopropanol, reversine (aza-reversien 2) was obtained at a $97 \%$ yield. Finally, as outlined in Scheme 1, biotin was coupled to aza-reversine 2 by using ECDI in DMF with DMAP at a 75\% yield.

3.2. Aza-Reversine 2 Induces Reprogramming of MRC-5 Cells to Osteoblasts and Differentiation of Mesenchymal Cells to Osteoblasts

Aza-reversine 2 was tested for its ability to induce the reprogramming of lung cells (MRC-5). MRC-5 cells were treated with $100 \mathrm{nM}$ of aza-revesrine 2 (diluted in $<1 \%$ DMSO) for 96 h, while control cells were treated only with DMSO. As shown in Figure 1, control cells increased in number and maintained their original form, while treated cells stopped proliferating and developed long branches, in accordance with previous studies [17]. MRC5 cells treated with aza-reversine 2 seem to be multinuclear (polyploidy). This phenotype is attributed to the inhibition of MPS1 kinase that is essential for the spindle assembly checkpoint [17]. 


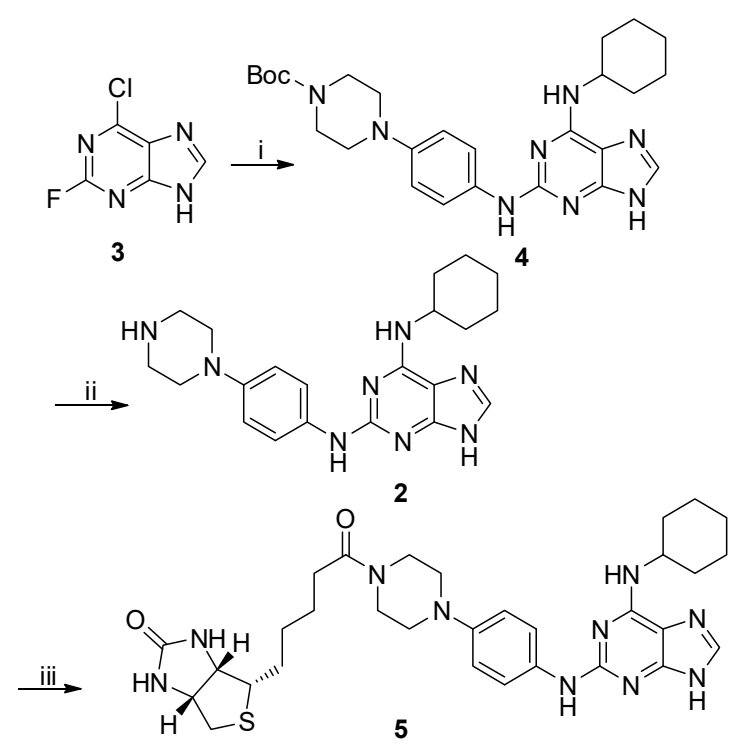

Scheme 1. Synthesis of biotinylated reversine probe. Reagents and conditions: (i) (a) cyclohexylamine, DIPEA, n-BuOH, $80{ }^{\circ} \mathrm{C}, 24 \mathrm{~h}$, (b) tert-butyl 4-(4-aminophenyl) piperazine-1-carboxylate, $\mathrm{EtOH}, 81 \%$ yield over two steps; (ii) $\mathrm{HCl}$, i-PrOH, 97\% yield; (iii) biotin, ECDI, DMAP, DMF, $75 \%$ yield.
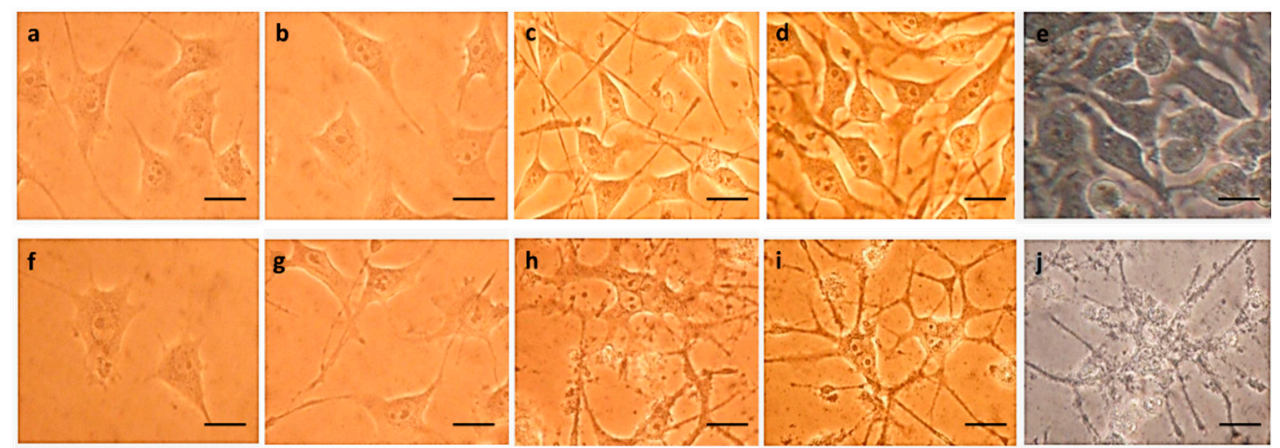

Figure 1. Morphological changes of MRC-5 cells induced by aza-reversine 2 (100 $\mathrm{nM}$ per well). (a-e) Control cells that were treated with DMSO (<1\%) after: (a) 0, (b) 24, (c) 48, (d) 72, (e) 96 h; (f-j) cells that were treated with 2 (100 nM/well) after: (f) 0, (g) 24, (h) 48, (i) 72, (j) 96 h. All images were taken using optical microscopy with $40 \times$ magnification. Scale bar: $0.5 \mu \mathrm{m}$.

After $96 \mathrm{~h}$, the medium was removed and replaced with an osteogenic differentiation medium (StemPro ${ }^{\circledR}$ Osteogenesis Kit, Invitrogen), and cells were collected after 12, 14 and 21 days of differentiation. On the 12th day of differentiation, mRNA was isolated from MRC-5 cells for testing the expression of osteocalcin with rt-PCR. Osteocalcin is a marker of osteogenesis and indicates the successful differentiation of cells into osteoblasts [22]. Gus-b (Beta-glucuronidase) was chosen as a housekeeping gene, and the results showed that treated cells expressed osteocalcin at a higher degree than untreated cells. Similar results were obtained with alkaline phosphatase assay and alizarin red stain. After 14 days, cells were tested for alkaline phosphatase activity, a characteristic marker of proliferating osteoblasts. Differentiated cells were colored blue-purple, while control cells were not stained [23,24]. Finally, after 21 days of osteogenic differentiation, treated cells were stained with alizarin red, a marker of extracellular calcium deposits formed during in vitro differentiation of osteoblasts. The results showed that cells treated with aza-reversine had a higher concentration of calcium deposits compared to control cells. Overall, the high expression of osteocalcin and the positive staining with alizarin red and alkaline phosphatase indicated that the cells treated with aza-reversine 2 were reprogrammed 
successfully and turned to osteoblasts under LSICs (lineage-specific inducing conditions) (Figure 2) and proposed that this modification did not alter the activity of reversine.
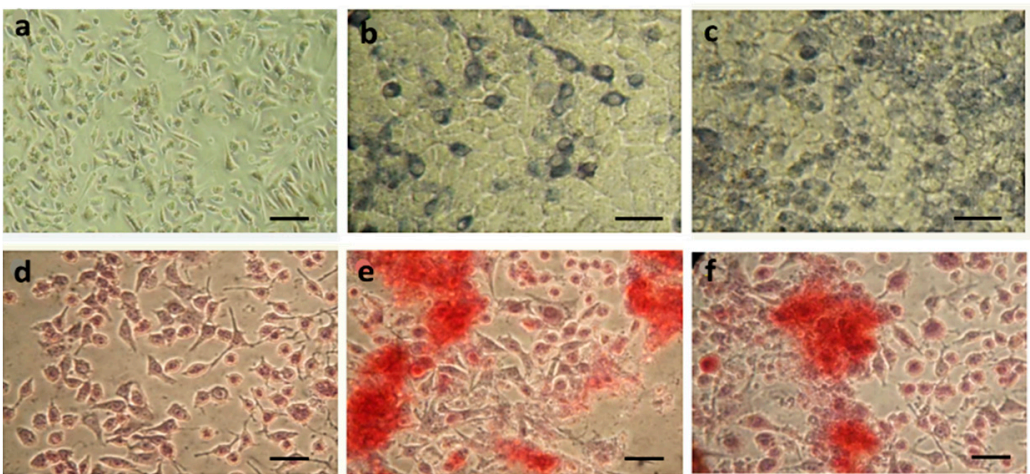

(A)

a

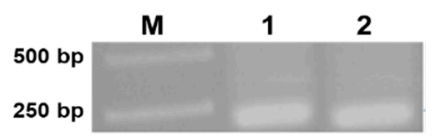

b

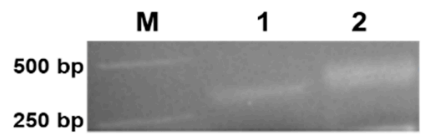

(B)

Figure 2. (A). (a-c) Detection of alkaline phosphatase activity in (a) control cells MRC-5 (treated with DMSO $<1 \%)$ and $(\mathbf{b}, \mathbf{c})$ MRC- 5 cells treated with $100 \mathrm{nM}$ of aza-reversine 2 . The differentiated cells are stained blue-purple and are more circular in shape, while control cells maintain their original morphology and are not stained positive for alkaline phosphatase. (d-f) Detection of extracellular calcium deposits after alizarin red staining of $(\mathbf{d})$ control cells (treated with DMSO $<1 \%)$ and $(\mathbf{e}, \mathbf{f})$ cells that were treated with $100 \mathrm{nM}$ of aza-reversine 2 . The calcium deposits are stained orange-red and indicate successful differentiation of the cells around them, while control cells remain colorless. Images (a-f) are taken using optical microscopy with $40 \times$ magnification. Scale bars: $0.5 \mu \mathrm{m}$. (B) Gel electrophoresis of rt-PCR products after amplification of (a) Gus-b. The template used was mRNA isolated from control cells (lane 1) and cells treated with aza-reversine 2 (lane 2). (b) Osteocalcin. The template used was mRNA isolated from control cells (lane 1) and cells treated with 2 (lane 2).

As mentioned above, a significant property of reversine is the ability to differentiate dental and adipose mesenchymal cells into osteoblasts. In another experiment, mesenchymal cells derived from dental tissue and adipose tissue were also treated with azareversine 2 , as previously described, in order to investigate if this property is affected after substitution. Osteogenic differentiation was tested with alizarin red stain and alkaline phosphatase activity. As shown in Figure 3, mesenchymal cells differentiated into osteoblasts after treatment with aza-reversine 2 at a concentration of $100 \mathrm{nM}$ for $48 \mathrm{~h}$ and cultured under osteogenic inducing conditions. These results are similar to previous findings, which show that reversine enhances the differentiation ability of mesenchymal cells [12]. 

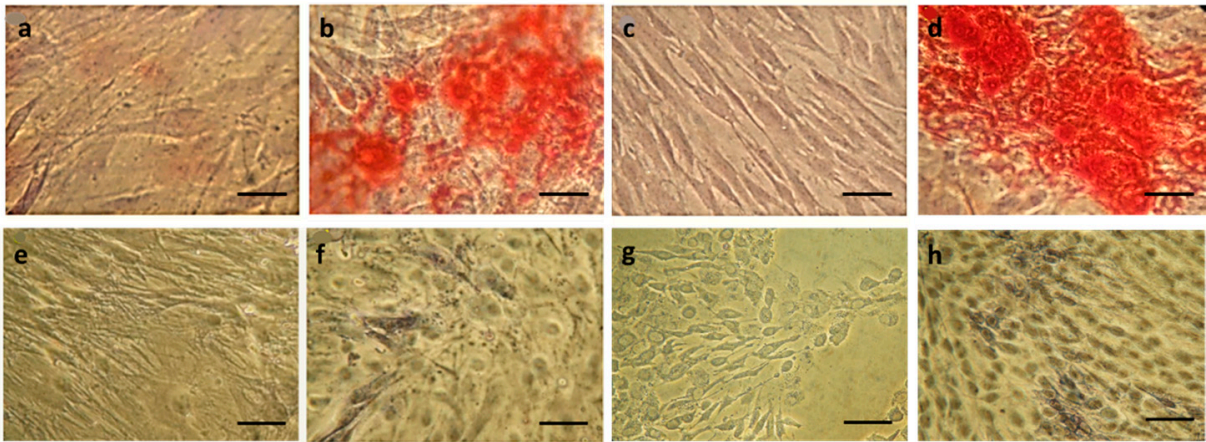

Figure 3. Alizarin red staining (a-d) and alkaline phosphatase staining (e-h) for the detection of differentiated mesenchymal cells to osteoblasts after treatment with aza-reversine $2(100 \mathrm{nM})(\mathbf{b}, \mathbf{d}, \mathbf{f}, \mathbf{h})$. Control cells were treated with DMSO $<1 \%(\mathbf{a}, \mathbf{c}, \mathbf{e}, \mathbf{g})$. The mesenchymal cells were isolated from adipose tissue $(\mathbf{a}, \mathbf{b}, \mathbf{e}, \mathbf{f})$ or dental tissue $(\mathbf{c}, \mathbf{d}, \mathbf{g}, \mathbf{h})$. Positive staining for alkaline phosphatase and alizarin red shows that mesenchymal cells were differentiated into osteoblasts. The circular shape of the differentiated cells is also a morphological characteristic of the osteoblasts, while the shape of mesenchymal cells is rod-like. All images are taken using optical microscopy with $40 \times$ magnification. Scale bars: $0.5 \mu \mathrm{m}$.

\subsection{Biotinylated Aza-Reversine 5 Reprograms MRC-5 Cells Prior and after Immobilization on Polymeric Surfaces}

Biotinylated aza-reversine 5 was also tested for its reprogramming and differentiation capacity on MRC- 5 cells (Figure 4). MRC- 5 cells were cultured and treated with biotinylated aza-reversine 5, similar to aza-reversine 2 as mentioned in paragraph 3.2. After reprogramming, cells were cultured with an osteogenic differentiation medium and were tested for alkaline phosphatase activity and alizarin red stain (on the 14th and 21st day of differentiation, respectively). As shown in Figure 4, treated cells were stained positively in both assays demonstrating that biotinylation did not affect the primitive properties of aza-reversine.
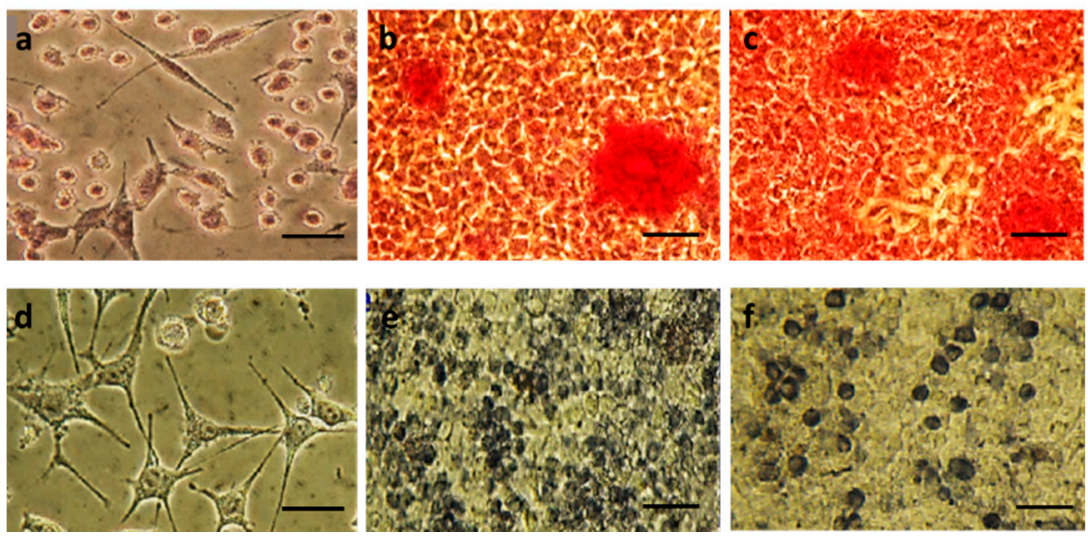

Figure 4. MRC-5 cells treated with biotinylated aza-reversine 2 . The differentiation to osteoblasts was determined with alizarin red staining $(\mathbf{a}-\mathbf{c})$ and alkaline phosphatase assay $(\mathbf{d}, \mathbf{e})$. The control cells $(\mathbf{a}, \mathbf{d})$ did not change their shape and were neither stained positive in both assays. The calcium deposits were positively stained in MRC-5 cultures that were treated with biotinylated $2(\mathbf{b}, \mathbf{c})$. Alkaline phosphatase staining $(\mathbf{e}, \mathbf{f})$ of treated MRC-5 cells confirmed the alizarin red staining findings. Scale bars: $0.2 \mu \mathrm{m}$.

After confirming that derivatives 2 and 5 are able to reverse the lineage-committed state of MRC- 5 cells to a more pluripotent state, further studies were conducted in order to investigate the differentiation capacity of immobilized aza-reversine 5 on polymeric surfaces. A variety of osteogenesis-inducing molecules immobilized on polymeric surfaces 
has been previously reported and applied to the design of implants used for the reconstruction of injured bone tissue [25-27]. According to our previous results, PMMA/HEMA polymeric surfaces are of great interest because they are non-toxic and can be easily biofunctionized with macromolecules [20]. Thus, it was interesting to examine the activity of polymeric surfaces carrying biotinylated aza-reversine 5 for further use in biological and medical applications. After the synthesis of the PMMA/HEMA polymeric surfaces as described in our previous study, the immobilization of aza-reversine on PMMA/HEMA polymeric surfaces was achieved through the non-covalent bond of streptavidin-biotin and verified by FTIR spectroscopy (See Supporting Information, Figure S1). After the immobilization of biotinylated aza-reversine 5 on PMMA/HEMA surfaces, MRC- 5 cells were cultured on them under osteogenic inducing conditions as described in Section 3.1 (Figure 5).
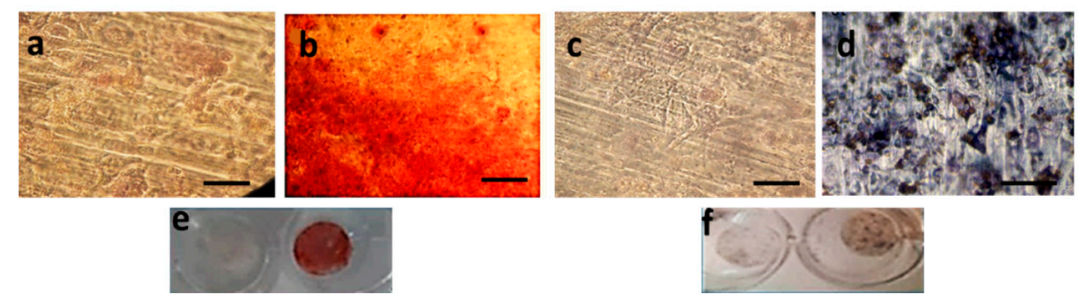

Figure 5. (a) MRC-5 cells after culturing on a non-modified PMMA-HEMA surface (control for alizarin red staining). (b) Alizarin red staining of the extracellular calcium deposits formed on the 21st day of osteogenesis. MRC-5 cells were reprogrammed and differentiated into osteoblasts by the immobilized 5 on PMMA-HEMA surfaces. (c) MRC- 5 cells on untreated surface PMMA-HEMA (control for alkaline phosphatase assay). (d) Detection of alkaline phosphatase activity in cultures of MRC-5 cells on biofunctionalized PMMA-HEMA surfaces. The immobilized biotinylated azareversine 5 maintains its reprogramming ability. (e) Samples of the surfaces used for alizarin red staining (Left: Unstained MRC-5 cells on PMMA-HEMA surface used as control. Right: MRC-5 cells on biofunctionalized PMMA-HEMA surface stained positively for alizarin red). Scale bars: $0.5 \mu \mathrm{m}$. (f) Samples of the surfaces used for alkaline phosphatase activity (Left: MRC- 5 on control PMMA-HEMA surfaces that were not differentiated into osteoblasts. Right: Reprogrammed MRC-5 stained for alkaline phosphatase on biofunctionalized PMMA-HEMA surfaces).

As recorded in the literature, biotinylated reversine shows similar effects on the differentiation of mesenchymal [1]. In our study, biotinylated aza-reversine 5 had similar reprogramming effects as aza-reversine 2 on mesenchymal cells, as shown in Figure 6.

Extracted alizarin red staining was quantified, and the results obtained showed that immobilized and free aza-reversine 2 seems to have a quite similar effect on MRC- 5 cells, while on mesenchymal cells, free aza-reversine induced the formation of calcium deposits at a higher degree.

In agreement with the previous results, immobilized aza-reversine remained active and induced MRC-5 cell reprogramming and mesenchymal cell osteogenic differentiation in a similar way to reversine. Alkaline phosphatase activity and alizarin red staining exhibited the differentiating capacity of immobilized aza-reversine 5 on PMMA/HEMA surfaces. As depicted in Figure 7, in MRC-5 cells, the high osteogenic potential is obtained with immobilized aza-reversine while in mesenchymal stem cells, free aza-reversine leads to high differentiation. 

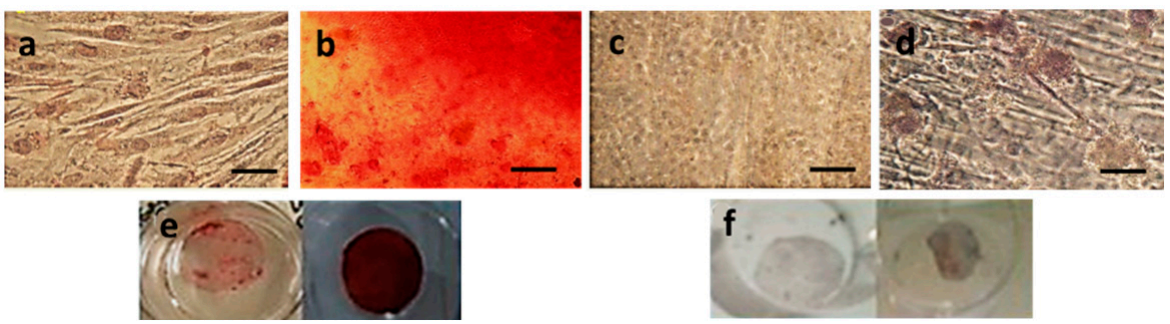

Figure 6. Alizarin red staining of (a) Mesenchymal cells on PMMA-HEMA surfaces that were used as the control (absence of 2). (b) Differentiated mesenchymal cells into osteoblasts on biofunctionalized PMMA-HEMA surfaces (immobilized 5). Alkaline phosphatase activity of (c) Mesenchymal cells used as control after alkaline phosphatase staining on PMMA-HEMA surfaces that were untreated differentiated mesenchymal cells into osteoblasts after culturing on PMMA-HEMA surfaces. (d) Immobilized 5 maintains its ability to enhance the differentiation process. (e) Differentiated mesenchymal cells into osteoblasts on biofunctionalized PMMA-HEMA surfaces (immobilized 5). (f) Samples of the surfaces used for alizarin red staining (Left: Mesenchymal cells on PMMA-HEMA surface used as control. Right: Mesenchymal cells on biofunctionalized PMMA-HEMA surface stained positively). (f) Samples of the surfaces used for alizarin red staining assay (Left: Mesenchymal cells on control PMMA-HEMA surfaces that were not differentiated into osteoblasts. Right: Reprogrammed mesenchymal cells stained for alkaline phosphatase on biofunctionalized PMMA-HEMA surfaces).

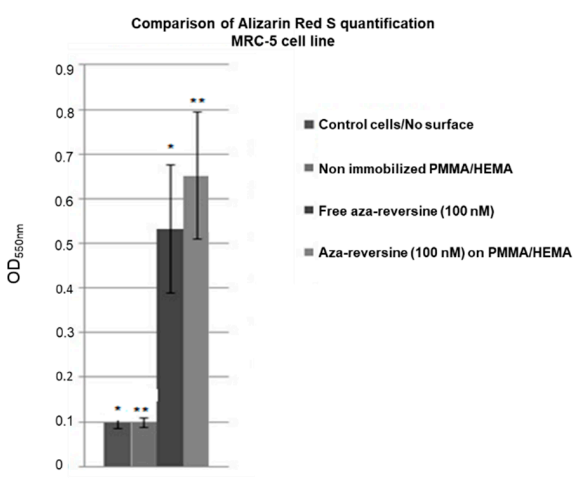

(a)

Comparison of Alizarin Red S quantification Dental mesenchymal cell line

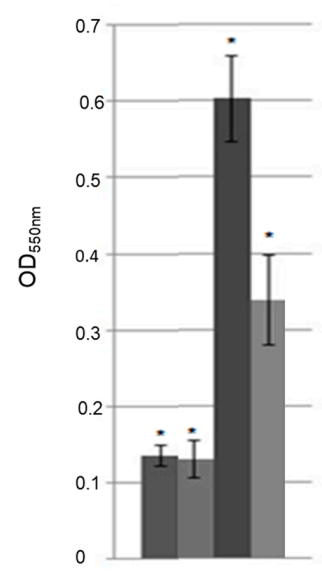

= Control cells/No surface

$=$ Non immobilized PMMA/HEMA

= Free aza-reversine $(100 \mathrm{nM})$

$=$ Aza-reversine (100 nM) on PMMA/HEMA

(b)

Figure 7. Alizarin red staining quantification of (a) MRC-5 cell reprogramming and (b) mesenchymal cell differentiation treated with free and with biotinylated, immobilized aza-reversine. Immobilized and free aza-reversine 2 seems to have a similar effect on MRC- 5 cells, while the activity of immobilized aza-reversine is decreased on mesenchymal cells. (Student's $t$-test, $\mathrm{n}=3,{ }^{*} p \leq 0.01$ statistically very important, ${ }^{* *} 0.05 \geq p>0.01$ statistically important). 


\section{Conclusions}

The current study focuses on the dual role of reversine as an agent that promotes cell dedifferentiation to a primitive state and decreases tumor progression. These key roles and the subsequent substitution without activity loss make reversine a promising molecule in a variety of medicinal applications. On this basis, a reversine analog, azareversine 2 , and its biotinylated derivative, 5 , were successfully synthesized and tested for their ability to reprogram MRC- 5 cells under osteogenic inducing conditions. Further, these derivatives were tested for their ability to differentiate mesenchymal stem cells into osteoblasts. Both aza-reversine and its biotinylated derivative induced in vitro osteogenesis of MRC-5 cells and mesenchymal cells under LISCs at a concentration of $100 \mathrm{nM}$. The concurrent conservation of activity after immobilization of the biotinylated derivative on polymeric surfaces through the strong non-covalent bond of streptavidin-biotin opens new horizons in biofunctionalized material construction that have both antitumorigenic and osteogenic capacities. The treatment of cancer cells co-includes several factors that have to be attacked by specific drugs. The usual problem that has to be faced nowadays is that the differences between cancer and non-cancer cells are not successfully distinguished. In particular, the specific delivery of the drug to its target requires cutting-edge, innovative technology with "intelligent substrates" capable of spontaneous target recognition as well as drug delivery. Thus, nanoparticles can be functionalized with biotinylated aza-reversine acting as an anti-cancer agent along with another molecule that recognizes healthy from diseased cells (cancer cells). The above suggestion is strongly based on the properties of this derivative regarding its capacity to be immobilized on thin layers, nanoparticles and scaffolds without abolishing its main function, which in low concentrations is the reprogramming of cells and in higher concentrations the killing agent of cancer cells. Further studies to determine the antitumorigenic capacity of these analogs in free and in biofunctionalized forms are needed.

Supplementary Materials: The following are available online at https:/ /www.mdpi.com/article/ 10.3390/ma14185385/s1, Figure S1: ${ }^{1} \mathrm{H}$ and ${ }^{13} \mathrm{C}$ NMR spectra of S1, Figure S2: ${ }^{1} \mathrm{H}$ and ${ }^{13} \mathrm{C}$ NMR spectra of 4, Figure S3: gDQCOSY spectrum of 4, Figure S4: ${ }^{1} \mathrm{H}$ and ${ }^{13} \mathrm{C}$ NMR spectra of 2, Figure S5: ${ }^{1} \mathrm{H}$ and ${ }^{13} \mathrm{C}$ NMR spectra of 5, Figure S6: Quantification of band intensity after rt-PCR (a) Gus-B, (b) osteocalcin.

Author Contributions: Conceptualization, T.C.-P.; Methodology, V.S. and A.K.; Investigation, F.T. and D.P.; Data Curation, F.T.; Writing—original draft preparation, V.S. and F.T.; Writing—Review and editing, M.P.; Supervision, T.C.-P.; Project Administration, T.C.-P.; Funding Acquisition, T.C.-P. All authors have read and agreed to the published version of the manuscript.

Funding: This research was funded by European Regional Development Fund of the European Union and Greek national funds through the Operational Program Competitiveness, Entrepreneurship and Innovation, under the call RESEARCH-CREATE-INNOVATE: T1EDK-04567.

Institutional Review Board Statement: Not applicable.

Informed Consent Statement: Not applicable.

Data Availability Statement: Not applicable.

Acknowledgments: This program was implemented within the framework of the Operational Pro.

Conflicts of Interest: The authors declare no conflict of interest.

\section{References}

1. Harding, J.; Mirochnitchenko, O.J. Preclinical studies for induced pluripotent stem cell-based therapeutics. Biol. Chem. 2014, 289, 4585-4593. [CrossRef]

2. Bouwens, L.; Houbracken, I.; Mfopou, J.K. The use of stem cells for pancreatic regeneration in diabetes mellitus. Nat. Rev. Endocrinol. 2013, 9, 598-606. [CrossRef] [PubMed]

3. Forbes, S.J.; Rosenthal, N. Preparing the ground for tissue regeneration: From mechanism to therapy. Nat. Med. $2014,20,857$. [CrossRef] [PubMed] 
4. Fox, I.J.; Daley, G.Q.; Goldman, S.A.; Huard, J.; Kamp, T.J.; Trucco, M. Use of differentiated pluripotent stem cells in replacement therapy for treating disease. Science 2014, 345, 6199. [CrossRef] [PubMed]

5. Zhang, Y.; Li, W.; Laurent, T.; Ding, S.J. Small molecules, big roles-The chemical manipulation of stem cell fate and somatic cell reprogramming. Cell Sci. 2012, 125, 5609-5620. [CrossRef]

6. Chen, S.; Zhang, Q.; Wu, X.; Schultz, P.G.; Ding, S.J. Dedifferentiation of lineage-committed cells by a small molecule. Am. Chem. Soc. 2004, 126, 410-411. [CrossRef]

7. Anastasia, L.; Sampaolesi, M.; Papini, N.; Oleari, D.; Lamorte, G.; Tringali, C.; Monti, E.; Galli, D.; Tettamanti, G.; Cossu, G.; et al. Reversine-treated fibroblasts acquire myogenic competence in vitro and in regenerating skeletal muscle. Cell Death Differ. 2006, 12, 2042-2051. [CrossRef]

8. Kim, Y.K.; Choi, H.Y.; Kim, N.H.; Lee, W.; Seo, D.W.; Kang, D.W.; Lee, H.Y.; Han, J.W.; Park, S.W.; Kim, S.N. Reversine stimulates adipocyte differentiation and downregulates Akt and p70s6k signaling pathways in 3T3-L1 cells. Biochem. Biophys. Res. Commun. 2007, 358, 553-558. [CrossRef]

9. Lee, E.K.; Bae, G.U.; You, J.S.; Lee, J.C.; Jeon, Y.J.; Park, J.W.; Park, J.H.; Ahn, S.H.; Kim, Y.K.; Choi, W.S.; et al. Reversine increases the plasticity of lineage-committed cells toward neuroectodermal lineage. J. Biol. Chem. 2009, 284, 2891-2901. [CrossRef]

10. Saraiya, M.; Nasser, R.; Zeng, Y.; Addya, S.; Ponnappan, R.K.; Fortina, P.; Anderson, D.G.; Albert, T.J.; Shapiro, I.M.; Risbud, M.V. Reversine enhances generation of progenitor-like cells by dedifferentiation of annulus fibrosus cells. Tissue Eng. Part A 2010, 16, 1443-1455. [CrossRef]

11. Lv, X.; Zhu, H.; Bai, Y.; Chu, Z.; Hu, Y.; Cao, H.; Liu, C.; He, X.; Peng, S.; Gao, Z.; et al. Reversine promotes porcine muscle derived stem cells (PMDSCs) differentiation into female germ-like cells. J. Cell Biochem. 2012, 113, 3629-3642. [CrossRef] [PubMed]

12. Conforti, E.; Arrigoni, E.; Piccoli, M.; Lopa, S.; de Girolamo, L.; Ibatici, A.; Di Matteo, A.; Tettamanti, G.; Brini, A.T.; Anastasia, L. Reversine increases multipotent human mesenchymal cells differentiation potential. Biol. Regul. Homeost. Agents 2011, 25, S25.

13. Perreira, M.; Jiang, J.-K.; Klutz, A.M.; Gao, Z.-G.; Shainberg, A.; Lu, C.; Thomas, C.J.; Jacobson, K.A.J. “Reversine” and its 2-substituted adenine derivatives as potent and selective A3 adenosine receptor antagonists. Med. Chem. 2005, 48, 4910-4918. [CrossRef]

14. Chen, S.; Takanashi, S.; Zhang, Q.; Xiong, W.; Zhu, S.; Peters, E.C.; Ding, S.; Schultz, P.G. Reversine increases the plasticity of lineage-committed mammalian cells. Proc. Natl. Acad. Sci. USA 2007, 104, 10482-10487. [CrossRef]

15. Morena D’Alise, A.; Amabile, G.; Iovino, M.; Di Giorgio, P.F.; Bartiromo, M.; Sessa, F.; Villa, F.; Musacchio, A.; Cortese, R. Reversine, a novel Aurora kinases inhibitor, inhibits colony formation of human acute myeloid leukemia cells. Mol. Cancer Ther. 2008, 7, 1140-1149.

16. Amabile, G.; D’Alise, A.M.; Iovino, M.; Jones, P.; Santaguida, S.; Musacchio, A.; Taylor, S.; Cortese, R. The Aurora B kinase activity is required for the maintenance of the differentiated state of murine myoblasts. Cell Death Differ. 2009, 16, 321-330. [CrossRef]

17. Santaguida, S.; Tighe, A.; D'Alise, A.M.; Taylor, S.S.; Musacchio, A. Dissecting the role of MPS1 in chromosome biorientation and the spindle checkpoint through the small molecule inhibitor reversine. J. Cell Biol. 2010, 190, 73-78. [CrossRef]

18. Piccoli, M.; Ghiroldi, A.; Monasky, M.M.; Cirillo, F.; Ciconte, G.; Pappone, C.; Anastasia, L. Reversine: A synthetic purine with a dual activity as a cell dedifferentiating agent and a selective anticancer drug. Curr. Med. Chem. 2020, 27, 3448-3462. [CrossRef] [PubMed]

19. VanderWel, S.N.; Harvey, P.J.; McNamara, D.J.; Repine, J.T.; Keller, P.R.; Quin, J., III; Booth, R.J.; Elliott, W.L.; Dobrusin, E.M.; Fry, D.W.; et al. Pyrido [2,3-d] pyrimidin-7-ones as specific inhibitors of cyclin-dependent kinase 4. J. Med. Chem. 2005, 48, 2371-2387. [CrossRef] [PubMed]

20. Tsitouroudi, F.; Karatza, A.; Karoulias, S.; Pantazaki, A.; Andriotis, E.G.; Achilias, D.S.; Choli-Papadopoulou, T. "In cell” biotinylation and immobilization of hBMP-2 (human Bone Morphogenetic Protein 2) on polymeric surfaces. Biochem. Eng. J. 2017, 123, 1-12. [CrossRef]

21. Bakopoulou, A.; Leyhausen, G.; Volk, J.; Papachristou, E.; Koidis, P.; Geurtsen, W. Wnt/ $\beta$-catenin signaling regulates dental pulp stem cells' responses to pulp injury by resinous monomers. Dent. Mater. 2015, 31, 542-555. [CrossRef] [PubMed]

22. Torii, Y.; Hitomi, K.; Yamagishi, Y.; Tsukagoshi, N. Demonstration of alkaline phosphatase participation in the mineralization of osteoblasts by antisense RNA approach. Cell Biol. Int. 2013, 20, 459-464. [CrossRef]

23. Gregory, C.A.; Gunn, W.G.; Peister, A.; Prockop, D.J. An Alizarin red-based assay of mineralization by adherent cells in culture: Comparison with cetylpyridinium chloride extraction. Anal. Biochem. 2005, 329, 77-84. [CrossRef] [PubMed]

24. Nakamura, A.; Dohi, Y.; Akahane, M.; Ohgushi, H.; Nakajima, H.; Funaoka, H.; Takakura, Y. Osteocalcin secretion as an early marker of in vitro osteogenic differentiation of rat mesenchymal stem cells. Tissue Eng. Part C Methods 2009, 15, 169-180. [CrossRef]

25. Karageorgiou, V.; Meinel, L.; Hofmann, S.; Malhotra, A.; Volloch, V.; Kaplan, D.J. Bone morphogenetic protein-2 decorated silk fibroin films induce osteogenic differentiation of human bone marrow stromal cells. Biomed. Mater. Res. A 2004, 71, 528-537. [CrossRef] [PubMed]

26. Tsujigiwa, H.; Nagatsuka, H.; Gunduz, M.; Rodriguez, A.; Rivera, R.S.; Legeros, R.Z.; Inoue, M.; Nagai, N. Effects of immobilized recombinant human bone morphogenetic protein-2/succinylated type I atelocollagen on cellular activity of ST2 cells. J. Biomed. Mater. Res. A 2005, 75, 210-215. [CrossRef]

27. Han, B.; Perelman, N.; Tang, B.; Hall, F.; Shors, E.C.; Nimni, M.E.J. Collagen-targeted BMP3 fusion proteins arrayed on collagen matrices or porous ceramics impregnated with Type I collagen enhance osteogenesis in a rat cranial defect model. Orthop. Res. 2002, 20, 747-755. [CrossRef] 